\title{
Thermohaline structure of Antarctic Bottom Water in the abyssal basins of the South Atlantic
}

\author{
D. I. Frey ${ }^{1}$, E. G. Morozov $^{1}$, I. Ansorge ${ }^{2}$, V. V. Fomin ${ }^{3}$, N. A. Diansky ${ }^{3,4,5}$, and R. Yu. Tarakanov ${ }^{1}$
}

Received 30 August 2019; accepted 5 September 2019; published 11 October 2019.

Antarctic Bottom Water (AABW) occupies the lowest ocean layer in the major part of the Atlantic. Despite the fact that this water has the same origin from the Weddell Sea, thermohaline properties of bottom layers vary strongly in different deep basins. Temperature and salinity increase along the pathways of bottom water propagation is caused by mixing of AABW with the warmer and more saline water in the overlying layers. This mixing strongly intensifies over underwater ridges; in addition, these ridges determine the pathways of bottom water spreading. Thus, the ocean topography plays the most important role in the formation of thermohaline structure of deep basins. In particular, the properties of AABW in the western and eastern parts of the South Atlantic significantly differ from each other. In this paper we compare temperature and salinity structure of the abyssal waters of the Southeast and Southwest Atlantic. We used the results of high spatial resolution modeling and hydrographic measurements for this study. We also simulated the velocity field in the bottom layer of the South Atlantic. KEYWORDS: Antarctic Bottom Water; deep-water processes; thermohaline structure; numerical modeling.

Citation: Frey, D. I., E. G. Morozov, I. Ansorge, V. V. Fomin, N. A. Diansky, and R. Yu. Tarakanov (2019), Thermohaline structure of Antarctic Bottom Water in the abyssal basins of the South Atlantic, Russ. J. Earth. Sci., 19, ES5005, doi:10.2205/2019ES000679.

\section{Introduction}

The Mid-Atlantic Ridge divides the Atlantic Ocean into two parts and causes significant differences between the deep and bottom waters of the West and East Atlantic. These waters originate in the Polar Regions; generally, colder and

\footnotetext{
${ }^{1}$ Shirshov Institute of Oceanology RAS, Moscow, Russia

${ }^{2}$ University of Cape Town, Rondebosch, South Africa

${ }^{3}$ Zubov State Oceanographic Institute, Moscow, Russia

${ }^{4}$ Lomonosov Moscow State University, Moscow, Russia

${ }^{5}$ Institute of Numerical Mathematics RAS, Moscow, Russia
}

Copyright 2019 by the Geophysical Center RAS. http://rjes.wdcb.ru/doi/2019ES000679-res.html denser Antarctic waters occupy the bottom layer while warmer and lighter North Atlantic waters are located above them [Johnson, 2008. The bottom water density difference in the basins of the South and North Atlantic is caused by the relatively shallow submarine ridges between Greenland, Iceland, the Faeroe Islands, and Scotland, which prevent the free propagation of cold bottom Arctic waters to the south [Dickson and Brown, 1994]. Despite the fact that North Atlantic Deep Water (NADW) overlies the ocean bottom in some parts of the North Atlantic [Mantyla and Reid, 1983, Orsi et al., 2001 almost all bottom layers of the Atlantic Ocean are occupied by AABW [Johnson, 2008. The classical definition of the boundary between these water masses is the isotherm of potential temperature $\theta=2{ }^{\circ} \mathrm{C}$ [ Wüst, 1936].

The formation of bottom waters occurs at a few 
locations on the Antarctic shelf of the Weddell Sea [Orsi et al., 1999, Warren, 1981]. After sinking to the abyssal depths, these waters mix with the Southern Ocean waters and form a northward flow of AABW in the South Atlantic [Ganachaud and Wunsch, 2000; Hogg et al., 1999, Lumpkin and Speer, 2007 Zenk and Hogg, 1996]. The properties of AABW change during its northward propagation. There are only two causes of these temperature and salinity variations: mixing with warmer and more saline layer of NADW and geothermal heating [Banyte et al., 2018, de Lavergne et al., 2016. The flow patterns of AABW strongly depend on the local topography. In particular, the coldest part of AABW propagates to the equator in the Southwest Atlantic because of the topographic obstacles in its southeastern part [Morozov et al., 2008, 2010. Thereby, thermohaline properties of bottom waters in different deep-water basins are quite different.

The goal of this work is to study the properties of temperature and salinity distributions in the abyssal basins of the South Atlantic. We used a three-dimensional ocean circulation model with high spatial resolution in the bottom layers for better description of the AABW structure. Two hydrographic sections were used for verification of the model and for studying the evolution of bottom water properties along the pathways of AABW propagation. Some integral characteristics of the waters in deep-water basins were also calculated.

\section{The Data and Methods}

Sparse direct observations in the abyssal ocean layer make investigations of bottom waters structure difficult. Simulations with modern numerical models focus on the calculation in the upper part of the ocean; usually, vertical resolution of these models in the deep layers is not sufficient for describing abyssal processes. In this work, we combined two approaches: first of all, we simulated the deep-water circulation using a regional model with a high resolution in the deep layers; in addition, we used direct hydrographic measurements for verification of the model and for detailed analysis of AABW evolution along the pathways of its spreading.
The Institute of Numerical Mathematics Ocean Model (INMOM) [Zalesny et al., 2010 was used for the simulations. The INMOM is a $\sigma$-coordinate numerical model based on the primitive equations of hydrothermodynamics with the Boussinesq and hydrostatic approximations [Diansky et al., 2002. Frey et al., 2017a, 2017b; Morozov et al., 2019. Zalesny et al., 2012. The model domain covered the part of the Atlantic Ocean from the equator to $50^{\circ} \mathrm{S}$, and from $60^{\circ} \mathrm{W}$ to $20^{\circ} \mathrm{E}$ (the domain is shown with thick black lines in Figure 1). The horizontal resolution was $0.05^{\circ}$ by latitude and longitude, which gives $1600 \times 1000$ model points in the horizontal plane. The domain covers the deep basins of the West and East Atlantic: Angola, Cape, Argentine, and Brazil basins are the regions, which we want to investigate and compare in this study.

The bottom relief was interpolated to the model domain from the GEBCO 2014 digital database [Weatherall et al., 2015]. The climatological data from the World Ocean Atlas 2013 [Locarnini et al., 2013. Zweng et al., 2013 were used as the initial temperature and salinity fields. These data were also specified in a buffer zone with a width of 10 grid points at the liquid boundaries [Klinck, 1995. The atmosphere-ocean interaction was prescribed by specifying the fluxes of heat, freshwater, and momentum at the boundary. The atmospheric characteristics included air temperature, humidity, and wind velocity at a height of $10 \mathrm{~m}$, atmospheric pressure, longwave and shortwave irradiance, and monthly mean precipitation. They were taken from the CORE database [Large and Yeager, 2009]. The numerical experiment was performed in two stages: at first, the model was spun up using "frozen" temperature and salinity fields; then, the simulation included adjustment of thermohaline properties. This method was suggested in [Sarkisyan, 1991] for computing the velocity field based on known temperature and salinity data.

Prognostic variables of the model are threedimensional fields of potential temperature, salinity, and components of horizontal velocity. Here, we analyzed temperature and salinity fields on the last day of the calculation. We used the data from two quasi-meridional hydrographic sections (the locations of stations over these sections are indicated with white dots in Figure 1). We chose these two sections because they follow the deep part of the basins in the West and East Atlantic and repre- 


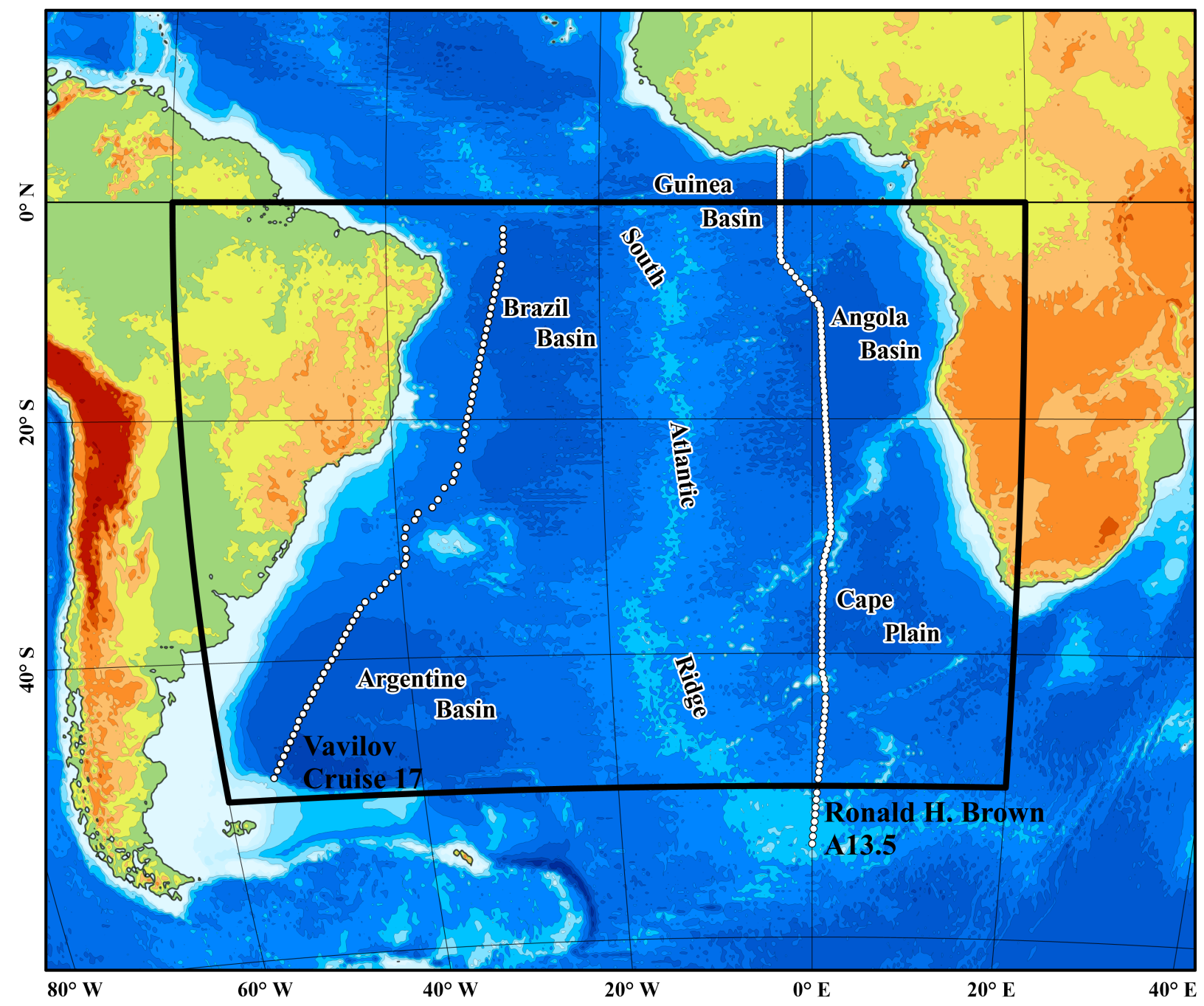

Figure 1. Bottom topography of the South Atlantic based on the GEBCO 2014 data [Weatherall et al., 2015. The model domain is shown with thick black lines. White dots show the two CTD sections occupied in cruise 17 of the R/V "Akademik Sergey Vavilov" [Morozov, 2005] and A13.5 section in the expedition of the R/V "Ronald H. Brown" [Bullister et al., 2010.

sent transformation of AABW properties. The first section across the Argentine and Brazil basins was occupied during cruise 17 of the $\mathrm{R} / \mathrm{V}$ "Akademik Sergei Vavilov" in 2003 [Morozov, 2005]. The route of this cruise covered the main pathway of Antarctic Bottom Water spreading. The data acquisition system consisted of a General Oceanics Rosette multi-bottle array system and Neil Brown CTD profiler. The second section across the eastern basins was carried out during the cruise of the $\mathrm{R} / \mathrm{V}$ "Ronald H. Brown" along line A13.5 [Bullister et al., 2010. The data were collected using Sea-Bird Electronics (SBE) 9plus CTD profiler mounted in a SBE 32 aluminum frame.

\section{Model Verification and Meridional Evolution of AABW Properties}

The results of numerical modeling were compared with the direct measurements over two sections in the West and East Atlantic (Figure 1) because bottom water structures in these two regions differ significantly. Quasi-meridional direction of these sections allows us to verify how the model reproduces the evolution of AABW properties. Moreover, the locations of stations in cruise 17 of the R/V "Akademik Sergei Vavilov" were especially chosen along the main pathway of AABW 

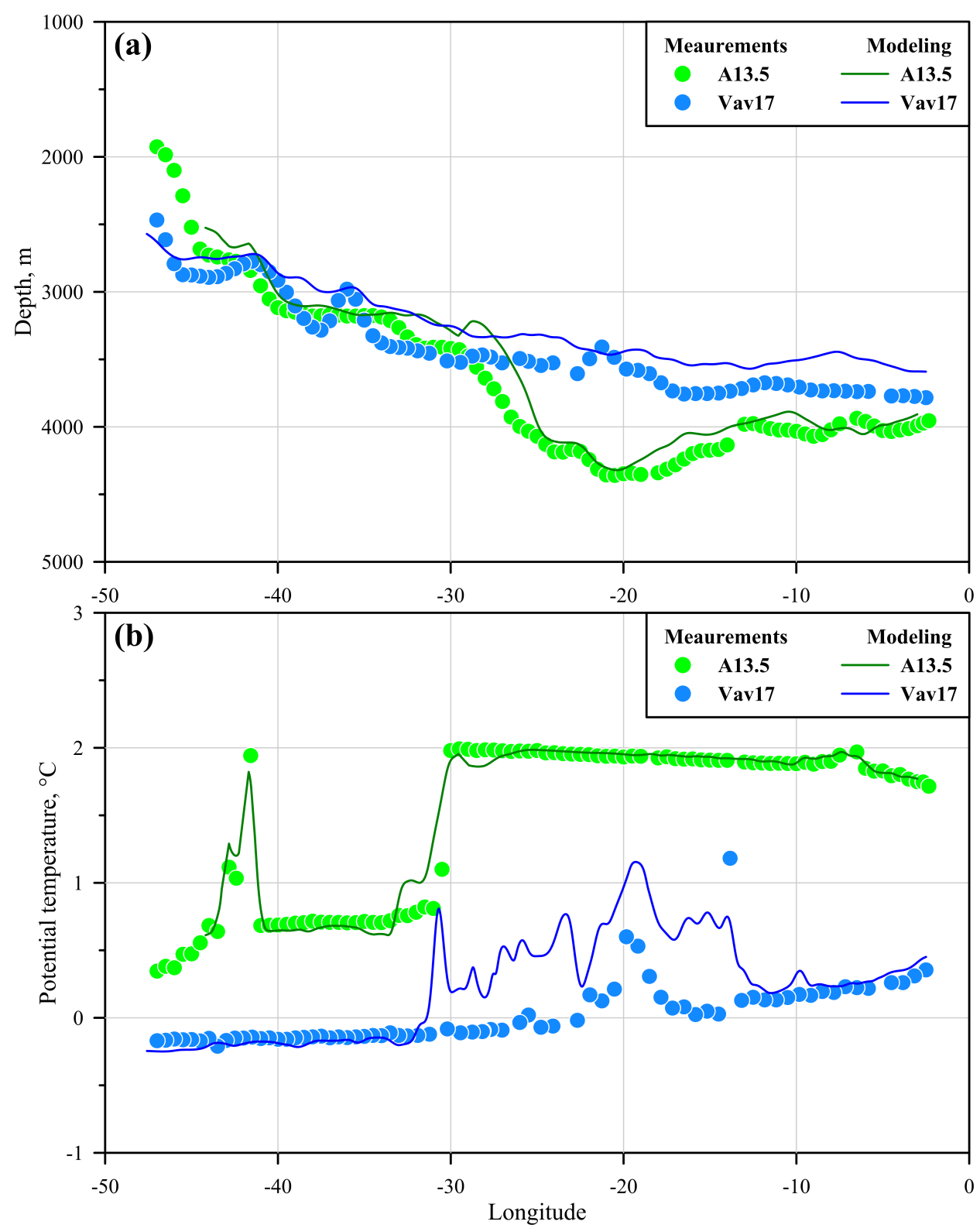

Figure 2. The data used for verification of the model: depth of $2^{\circ} \mathrm{C}$ potential temperature isotherm (a) and potential temperature at the ocean bottom (b) along the hydrographic sections in the West (shown with blue colors) and East (green colors) Atlantic. Circles indicate the values at the CTD-stations; solid lines are the data of numerical modeling interpolated to the trajectory of the sections. Some statistical parameters of these data are given in Table 1 .

spreading. These stations include the Vema Channel with the most intense flow of $\mathrm{AABW}$ in the Atlantic. In the channel, CTD casts were performed near its eastern wall [Morozov, 2005], because the Ekman friction moves the coldest waters to the right relatively to the main northward flow (in the Southern Hemisphere). This effect was investigated in the Vema Channel numerically [Jungclaus and Vanicek, 1999] and observed many times in different expeditions [Morozov et al., 2008, 2010. The flow of AABW from the Vema Channel was studied in [Morozov et al., 2018.

The data used for verification are shown in Figure 2. We compared two properties of AABW: the depth of its upper boundary (Figure 2a), and potential temperature at the ocean bottom (Figure $2 \mathrm{~b}$ ). The stations occupied in cruise 17 of the $\mathrm{R} / \mathrm{V}$ "Akademik Sergei Vavilov are shown with blue 
Table 1. Verification of the Model on the Basis of Two CTD-Sections. $X_{\text {model }}$ and $X_{\text {meas }}$ are Modeled and Measured Values, Respectively. These Values Include Calculated Upper Boundary of AABW and Potential Temperature at the Ocean Bottom

\begin{tabular}{lcccc}
\hline & Maximum & Minimum & Mean & $\begin{array}{c}\text { Standard } \\
\text { deviation }\end{array}$ \\
& $\left(X_{\text {model }}-X_{\text {meas }}\right)$ & $\left(X_{\text {model }}-X_{\text {meas }}\right)$ & $\left(X_{\text {model }}-X_{\text {meas }}\right)$ & $\left(X_{\text {model }}-X_{\text {meas }}\right)$ \\
\hline AABW level (East), $\mathrm{m}$ & 103 & -402 & -117 & 109 \\
AABW level (West), $\mathrm{m}$ & 217 & -303 & -159 & 101 \\
Bottom pot. temp. (East), ${ }^{\circ} \mathrm{C}$ & 0.55 & -0.20 & 0.018 & 0.110 \\
Bottom pot. temp. (West), ${ }^{\circ} \mathrm{C}$ & 0.66 & -0.85 & 0.092 & 0.401 \\
\hline
\end{tabular}

color, and stations from the A13.5 section occupied in the cruise of the R/V "Ronald H. Brown" are shown with green. Solid lines in Figure 2 correspond to the results of our numerical modeling. Bottom temperatures were determined as the temperature of the closest to the bottom sample; usually the CTD cast was stopped at 3-5 meters above the sea floor. As for numerical modeling, potential temperature from the lowest sigma-level was used for comparison with the measured value. The location of the $2{ }^{\circ} \mathrm{C}$ isotherm at the station was determined by linear interpolation of the temperature profile between samples; the same approach was used for simulated data.

The simulated data presented in Figure 2 were interpolated to the points of measurements for model verification. Parameters of data comparison are shown in Table 1. Standard deviation of the difference between simulated and measured values is about 100 meters over both sections. Simulated bottom potential temperatures over the A13.5 section agree well with the measurements (the mean difference is $0.018^{\circ} \mathrm{C}$ and standard deviation is $\left.0.11^{\circ} \mathrm{C}\right)$. As can be seen from Figure $2 \mathrm{~b}$, the temperatures in the West Atlantic at latitudes of $32^{\circ}-$ $15^{\circ} \mathrm{S}$ differ significantly. One of the causes of this discrepancy is the narrowness of the Vema Channel located at this part of the section. The resolution of the model does not allow one to restore the AABW flow adequately; thus, simulated values do not agree with the correctly measured ones. The correct simulation is presented in [Frey et al., 2017a using the same model with much higher horizontal resolution.

\section{AABW Structure and Velocities in the Bottom Layer of the Atlantic}

The results of numerical modeling allow us to study the spatial structure of bottom waters in the South Atlantic. For this analysis, we interpolated three-dimensional temperature and salinity fields from vertical sigma-levels to regular $z$-levels with high resolution. Using interpolated data, we calculated horizontal velocities in the AABW layer in the entire South Atlantic (Figure 3). Here we present the velocities at a depth of $4300 \mathrm{~m}$, which corresponds to a depth of the main flow in the Vema Channel. Generally, these velocities do not exceed $5 \mathrm{~cm} / \mathrm{s}$; more intense flows are observed in the western part of the Argentine Basin and in the Vema Channel. Correct modeling of these flows requires higher resolution. The main feature of the bottom circulation in the western part of the South Atlantic is the bottom flow of the Deep Western Boundary Current directed to the north. This current is clearly pronounced south of the Rio Grande Rise (south of $30^{\circ} \mathrm{S}$ ). Strong intensification of the bottom current occurs in the Vema Channel $\left(27^{\circ}-33^{\circ} \mathrm{S}\right)$. Based on the numerical modeling, the northerly current becomes less intense north of $27^{\circ} \mathrm{S}$ and almost disappears in the northern part of the Brazil Basin. However, direct measurements in the ocean reveal that the northerly bottom flow continues further to the equator and north of the equator [Sandoval and Weatherly, 2001.

In the East Atlantic, the inflow of AABW to the Angola Basin based on numerical simulations is revealed in the southern part of the Angola Basin. 


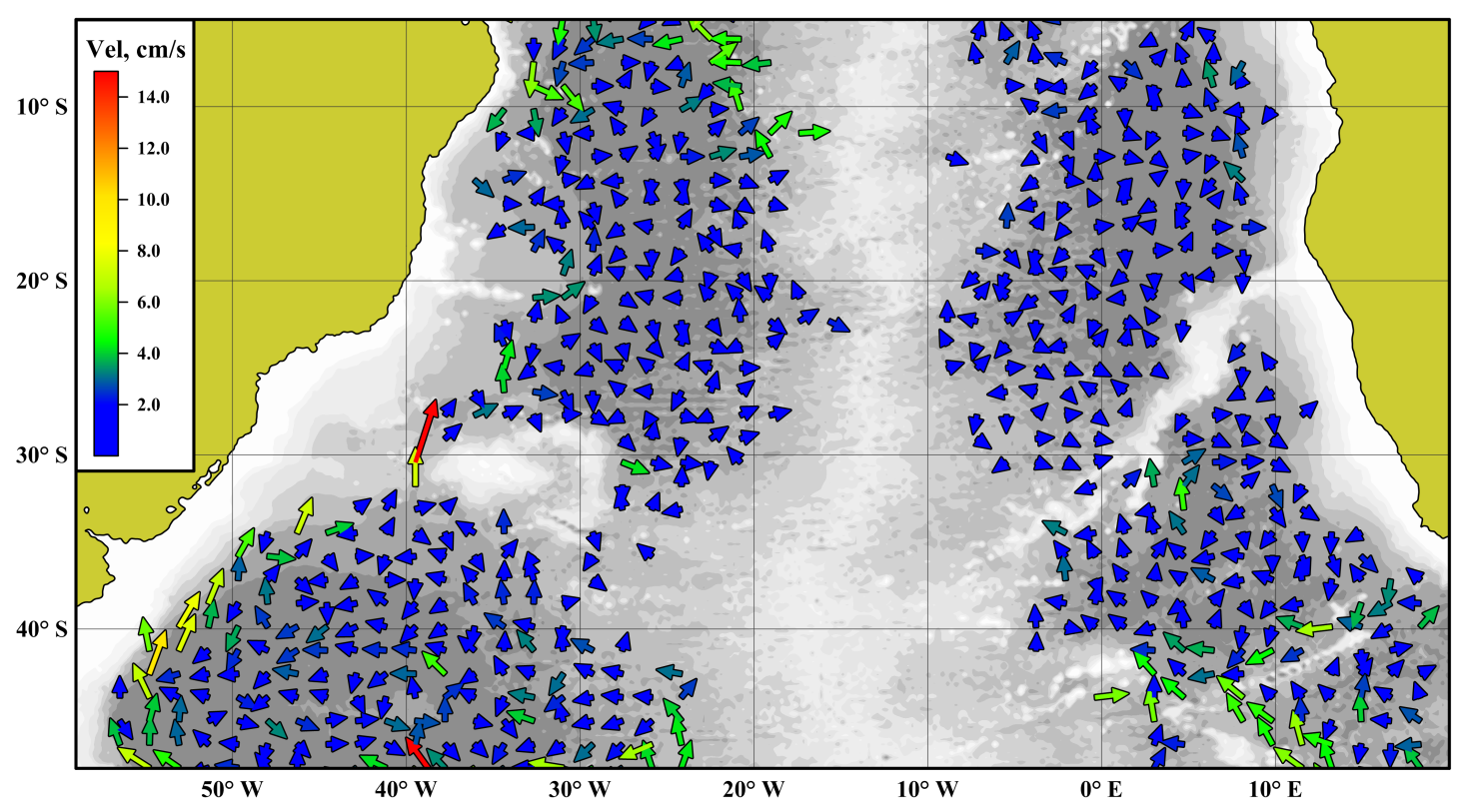

Figure 3. Vectors of horizontal velocities at a depth of a $4300 \mathrm{~m}$ in the South Atlantic based on the results of numerical modeling.

This conclusion was also made in [Morozov et al., 2010. The circulation in the bottom layer of the Angola Basin is generally very weak.

Some aspects of deep-water circulation in this region are discussed in [Frey et al., 2017b]. Distribution of bottom potential temperature (Figure 4 ) is helpful for determining the main pathways of AABW spreading. The values of potential temperature were taken from the bottom $\sigma$-level of our model.

We calculated some integral parameters of AABW in the main basins of the South Atlantic. The parameters include minimum potential temperature and salinity, maximum potential density referenced to $4000 \mathrm{db}\left(\sigma_{4}\right)$, and total volume of Antarctic waters below the $2^{\circ} \mathrm{C}$ potential temperature isotherm (Table 2). The calculation was made for the Argentine, Brazil, Cape, and Angola basins separately. Minimum temperatures were determined from the deepest sigma-level of the model. Usually, the waters with the minimum temperatures are located in the deep part of the basins near the channel with inflow of bottom waters. The minimum salinity in Table 2 was determined as salinity at the points with minimum temperature. Then, maximum potential density referenced to $4000 \mathrm{db}$ was derived using the EOS80 equations [Lewis and Perkin, 1981. Three-dimensional temperature field interpolated to the $z$-levels was used for the calculation of the AABW volume. Horizontal resolution of the field was $0.05^{\circ}$ (the same as the model resolution), the vertical resolution was 20 meters. Then, we made the following check for

Table 2. AABW Properties in Deep Basins of the South Atlantic Based on the Numerical Simulation

\begin{tabular}{lcccc}
\hline Basin & $\begin{array}{c}\text { Minimum pot. } \\
\text { temperature, }{ }^{\circ} \mathrm{C}\end{array}$ & $\begin{array}{c}\text { Minimum } \\
\text { salinity, psu }\end{array}$ & $\begin{array}{c}\text { Maximum density } \\
\sigma_{4}, \mathrm{~kg} / \mathrm{m}^{3}\end{array}$ & $\begin{array}{c}\text { Total AABW } \\
\text { volume, } 10^{6} \mathrm{~km}^{3}\end{array}$ \\
\hline Argentine & -0.25 & 34.67 & 46.09 & 10.8 \\
Brazil & 0.15 & 34.69 & 46.05 & 9.2 \\
Cape & 0.6 & 34.71 & 45.99 & 5.6 \\
Angola & 1.9 & 34.88 & 45.88 & 3.5 \\
\hline
\end{tabular}




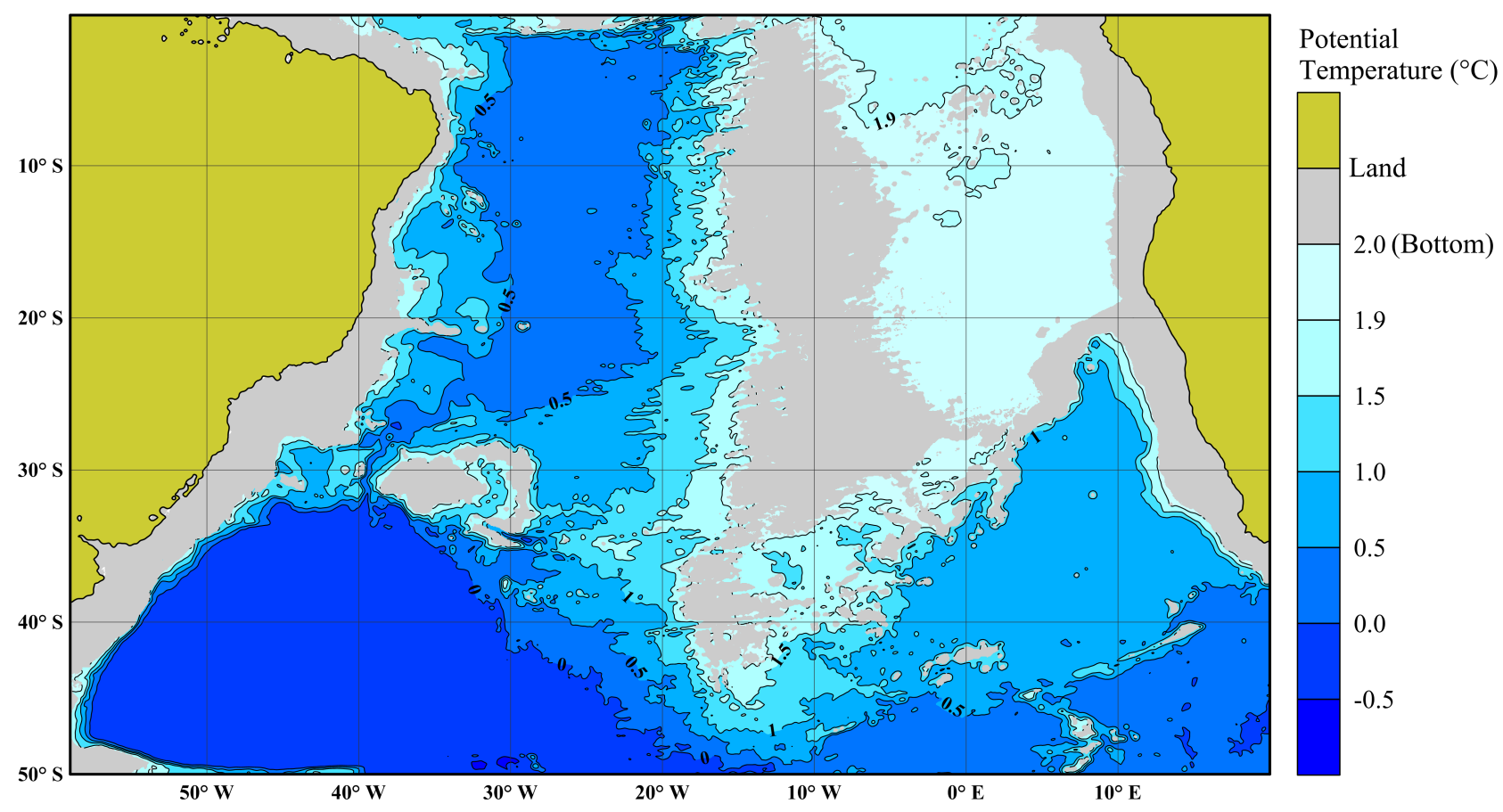

Figure 4. Bottom potential temperature in the bottom layer of the Atlantic. The data were taken from the deepest $\sigma$-level of the model. The ocean basins with bottom potential temperature greater than $2^{\circ} \mathrm{C}$ are shown with gray color.

each point of the grid: if potential temperature $\theta$ was lower than $2^{\circ} \mathrm{C}$ and location of the node was above the bottom, then this volume was added to the corresponding ocean basin. We can see that the AABW volume in the West Atlantic is two times larger than in the East Atlantic; in addition, the waters west of the Mid-Atlantic Ridge are colder and less saline, which makes their density higher (Table 2).

\section{Summary and Conclusions}

Temperature and salinity structure of bottom waters in deep basins of the South Atlantic were studied on the basis of two hydrographic quasimeridional sections and simulations using a numerical model with a high resolution in the abyssal ocean layer. The model was verified using the CTD data from these sections. In this study, we focused on the transformation of bottom waters over the pathway of their propagation and on the zonal differences of $\mathrm{AABW}$ in the western and eastern parts of the South Atlantic Ocean. Some integral characteristics of bottom waters were calculated for the individual ocean basins, including the Argentine, Brazil, Cape, and Angola basins. The main results of our research related to the numerical simulations and model adjustment are as follows:

1. An adjusted version of the ocean circulation model was applied for investigations of the abyssal ocean layer, including the main pathways of bottom waters and influence of underwater ridges and other features of bottom topography on the spatial structure of deep waters. Narrow abyssal channels are key points of AABW propagation and require sufficient horizontal resolution of the model as well as additional verification.

2. Significant increase in the bottom temperature is observed over underwater ridges along the pathway of AABW propagation. In addition, its upper boundary becomes much deeper. For example, after crossing the ridge at $30^{\circ} \mathrm{S}$ in the Southeast Atlantic, the bottom potential temperature increases from $0.7^{\circ} \mathrm{C}$ up to $1.9^{\circ} \mathrm{C}$, while the $2^{\circ} \mathrm{C}$ isotherm descends by almost $1 \mathrm{~km}$.

3. Strong differences are observed in the abyssal waters in the Southwest and Southeast At- 
lantic due to the local peculiarities of the bottom topography. Thus, the total volume of AABW in the West Atlantic is two times greater than in the East Atlantic; the bottom temperature variations between them reach $2^{\circ} \mathrm{C}$ over the same zonal section.

4. The flow of AABW to the north is generally concentrated in the abyssal Deep Western Boundary Current. It is well pronounced in the Argentine Basin but becomes weaker in the Brazil Basin.

Acknowledgments. The work was carried out within the State Task of the Russian Federation 0128-20190009; the research was supported by the Russian Foundation for Basic Research (grant 19-57-60001, numerical simulations, and 19-05-00878, model adjustment) and by the Russian Science Foundation (grant 16-17-10149, data analysis). The work of I. Ansorge was supported by the National Research Foundation of South Africa (Grant UID 118901).

\section{References}

Banyte, D., M. Morales Maqueda, R. Hobbs, D. A. Smeed, A. Megann, S. Recalde (2018), Geothermal Heating in the Panama Basin: 1. Hydrography of the Basin, J. Geophys. Res., 123, No. 10, 7382-7392, Crossref

Bullister, J. L., R. A. Feely, R. Wanninkhoff, A. G. Dickson, D. A. Hansell, R. M. Key (2010), Carbon dioxide, hydrographic, and chemical data obtained during the $R / V$ Ronald $H$. Brown Cruise in the Atlantic Ocean on CLIVAR repeat hydrography section A13.5 (Mar. 08-Apr. 17, 2010), Carbon Dioxide Information Analysis Center, Oak Ridge National Laboratory, U.S. Department of Energy, Oak Ridge. Crossref

De Lavergne, C., G. Madec, J. Le Sommer, A. G. Nurser, A. C. Naveira Garabato (2016), On the consumption of Antarctic Bottom Water in the abyssal ocean, J. Phys. Oceanography, 46, No. 2, 635-661, Crossref

Diansky, N. A., A. V. Bagno, V. B. Zalesny (2002), Sigma model of global ocean circulation and its sensitivity to variations in wind stress, Izv. Atmosph. Oceanic Phys., 38, No. 4, 537-556.

Dickson, R. R., J. Brown (1994), The production of North Atlantic Deep Water: Sources, rates, and pathways, J. Geophys. Res., 99, 12,319-12,342, Crossref

Frey, D. I., V. V. Fomin, N. A. Diansky, et al. (2017a), New model and field data on estimates of Antarctic
Bottom Water flow through the deep Vema Channel, Doklady Earth Sciences, 474, No. 1, 561-564, Crossref

Frey, D. I., A. N. Novigatsky, M. D. Kravchishina, E. G. Morozov (2017b), Water structure and currents in the Bear Island Trough in July-August 2017, Russ. J. Earth. Sci., 17, ES3003, Crossref

Ganachaud, A., C. Wunsch (2000), Improved estimates of global ocean circulation, heat transport and mixing from hydrographic data, Nature, 408, 453-457, Crossref

Hogg, N., G. Siedler, W. Zenk (1999), Circulation and variability at the Southern Boundary of the Brazil Basin, J. Phys. Oceanogr., 29, 145-157, Crossref

Johnson, G. C. (2008), Quantifying Antarctic Bottom Water and North Atlantic Deep Water volumes, J. Geophys. Res., 113, C05027, Crossref

Jungclaus, J., M. Vanicek (1999), Frictionally modified flow in a deep ocean channel: Application to the Vema Channel, J. Geophys. Res., 104, No. C9, 21,123-21,136, Crossref

Klinck, J. M. (1995), Thermohaline structure of an eddy-resolving North-Atlantic model: The influence of boundary conditions, J. Physical Oceanography, 25, 1174-1196, Crossref

Large, W., S. Yeager (2009), The global climatology of an interannually varying air-sea flux data set, Clim. Dyn., 33, 341-364, Crossref

Lewis, E. L., R. G. Perkin (1981), The Practical Salinity Scale 1978: conversion of existing data, DeepSea Research, 28A, No. 4, 307-328, Crossref

Locarnini, R. A., A. V. Mishonov, J. I. Antonov, et al. (2013), World Ocean Atlas 2013, Vol. 1: Temperature, S. Levitus (ed.), A. Mishonov (techn. ed.), 40 pp. NOAA Atlas NESDIS 73, USA. (http://www.nodc.noaa.gov/OC5/indprod.ht ml)

Lumpkin, R., K. Speer (2007), Global ocean meridional overturning, J. Physical Oceanography, 37, 2550-2562, Crossref

Mantyla, A. W., J. L. Reid (1983), Abyssal characteristics of the World Ocean waters, Deep-Sea Res., Part A, 30, 805-833, Crossref

Morozov, E. G. (2005), Cruise 17 of R/V Akademik Sergei Vavilov in the Atlantic Ocean, Oceanology, 45, No. 3, 441-443.

Morozov, E. G., A. N. Demidov, R. Yu. Tarakanov (2008), Transport of Antarctic waters in the deep channels of the Atlantic Ocean, Doklady Earth Sciences, 423, No. 8, 1286-1289, Crossref

Morozov, E. G., A. N. Demidov, R. Yu. Tarakanov, W. Zenk (2010), Abyssal Channels in the Atlantic Ocean: Water Structure and Flows, 266 pp. Springer, Dordrecht. Crossref

Morozov, E. G., R. Yu. Tarakanov, D. I. Frey, D. G. Borisov (2018), Currents and water structure north of the Vema Channel, Russian Journal of Earth Sciences, 18, ES5006, Crossref

Morozov, E. G., D. I. Frey, N. A. Diansky, V. V. Fomin (2019), Bottom circulation in the 
Norwegian Sea, Russian Journal of Earth Sciences, 19, ES2004, Crossref

Orsi, A. H., G. C. Johnson, J. L. Bullister (1999), Circulation, mixing, and production of Antarctic Bottom Water, Prog. Oceanogr., 43, 55-109, Crossref

Orsi, A. H., S. S. Jacobs, A. L. Gordon, M. Visbeck (2001), Cooling and ventilating the abyssal ocean, Geophys. Res. Lett., 28, 2923-2926, Crossref

Sandoval, F. J., G. L. Weatherly (2001), Evolution of the Deep Western Boundary Current of Antarctic Bottom Water in the Brazil Basin, J. Physical Oceanography, 31, No. 6, 1440-1460, Crossref

Sarkisyan, A. S. (1991), Simulation of Oceanic Dynamics, Gidrometeoizdat, St. Petersburg. (in Russian)

Zalesny, V. B., N. A. Diansky, V. V. Fomin, S. N. Moshonkin, S. G. Demyshev (2012), Numerical model of the circulation of the Black Sea and the Sea of Azov, Russ. J. Numerical Analysis Mathematical Modelling, 27, No. 1, 95-111, Crossref

Zalesny, V. B., G. I. Marchuk, V. I. Agoshkov, et al. (2010), Numerical simulation of large-scale ocean circulation based on the multicomponent splitting method, Russ. J. Numerical Analysis Mathematical Modelling, 25, No. 6, 581-609, Crossref

Zenk, W., N. G. Hogg (1996), Warming trend in Antarctic Bottom Water flowing into the Brazil
Basin, Deep-Sea Res. I, 43, No. 9, 1461-1473, Crossref

Zweng, M. M., J. R. Reagan, J. I. Antonov, et al. World Ocean Atlas 2013, Vol. 2: Salinity, S. Levitus (ed.), A. Mishonov (techn. ed.), 39 pp. NOAA Atlas NESDIS 74, USA. (http://www.nodc.noaa.gov/ OC5/indprod.html)

Warren, B. A., C. Wunsch, (Eds.) (1981), Deep circulation of the world ocean, Evolution of Physical Oceanography, B. A. Warren and C. Wunsch (Eds.) p. 6-41, MIT Press, Cambridge, Mass.

Weatherall, P., K. M. Marks, M. Jakobsson, et al. (2015), A new digital bathymetric model of the world's oceans, Earth and Space Science, 2, No. 8, 331-345, Crossref

Wüst, G. (1936), Schichtung und Zirkulation des Atlantischen Ozeans (ed. Defant A.) Wissenschaftliche Ergebnisse, Deutsche Atlantische Expedition auf dem Forschungs - und Vermessungsschiff "Meteor" 19251927, Walter de Gruyter \& Co., Berlin.

Corresponding author:

E. G. Morozov, Shirshov Institute of Oceanology, Russian Academy of Sciences, Nakhimovskii prospect 36, 117997 Moscow, Russia. (egmorozov@mail.ru) 